\title{
RESEARCH ON SOLAR ENERGY COLLECTOR WITH CELL POLYCARBONATE ABSORBER
}

\section{Henriks Putans, Viktorija Zagorska, Imants Ziemelis, Zanis Jesko}

Latvia University of Agriculture, Research Institute of Agricultural Machinery Henriksooo@inbox.lv; vzagorska@gmail.com; Imants.Ziemelis@1lu.lv; Zanis.Jesko@1lu.lv

\begin{abstract}
A flat plate solar collector with cell polycarbonate absorber and transparent cover has been made and its experimental investigation carried out. The collector consists of a wooden box, into which, a layer of heat insulation with a mirror film and $4 \mathrm{~mm}$ thick cell polycarbonate sheet, as the absorber, are placed. The coherence between collector's efficiency, heat carrier and ambient air temperature, as well as intensity of the solar radiation and heat power in the experimental investigation has been obtained. During the experimental examination the maximum temperature of the heat carrier reached $80^{\circ} \mathrm{C}$ at the intensity of solar radiation about $0.8 \mathrm{~kW} / \mathrm{m}^{2}$ and ambient air temperature around $32^{\circ} \mathrm{C}$. The efficiency of the collector reached $33-60 \%$, depending on the intensity of solar radiation and surrounding air temperature.
\end{abstract}

Keywords: solar collector, cell polycarbonate, power.

\section{Introduction}

The solar insulation, coming from the sun to the earth, perpendicularly to the atmosphere highest layers is about $1353 \mathrm{~W} / \mathrm{m}^{2}$, which is called the solar constant [1]. Going through the earth atmosphere up to $50 \%$ of direct solar radiation is absorbed by the layer of ozone, air and water vapour molecules, particles of dust, and turns into diffuse one. This part depends on the geographical and climatic conditions of the place. The intensity of direct solar radiation on the earth surface can reach $1 \mathrm{~kW} / \mathrm{m}^{2}$, but the amount of solar energy on the earth horizontal surface at our latitude can be up to $1000 \mathrm{kWh} / \mathrm{m}^{2}$.

The energy of solar radiation is used for the production of heat, electric and mechanical energy. Passive and active solar heating systems are used. In passive systems the function of the absorber and cover is realised by the elements of the premises to be heated (windows, walls, floor), and the air circulation goes on in the way of convection. Active solar systems are solar collectors, used for water or air heating. For water heating flat plate and vacuum tube collectors widely are used.

In the majority of presently produced solar collectors, solar energy absorbers from nonferrous metals $(\mathrm{Cu}, \mathrm{Al})$ are made. As a transparent cover hardened glass, which is relatively heavy and brittle, usually is chosen. Regardless of good thermo-technical parameters and long service time of these collectors, they are heavy (about $35 \mathrm{~kg} / \mathrm{m}^{2}$ ) and expensive, what hampers the wide utilization of them in Latvia. Therefore scientists in the entire globe are searching for new materials appropriate for the production of lighter, cheaper and more durable constructions of solar collectors. One of such materials is transparent cell polycarbonate (CPC) sheet, consisting of side by side placed squared canals. They can work at the wide range of temperature $\left(-40 \ldots+100^{\circ} \mathrm{C}\right.$, in short-term up to $\left.+120^{\circ} \mathrm{C}\right)$, have good solar radiation penetrability $(\tau>0.8)$, are light, flexible and mechanically durable. Therefore investigation in this direction is considered as perspective.

\section{Materials and methods}

The cell polycarbonate collector is performed as a classic flat plate solar collector (Fig.1). It consists of a box, into which, a layer of heat insulation with a mirror film and $4 \mathrm{~mm}$ thick cell polycarbonate sheet, as the absorber, are placed. The front side of the collector box (directed to the sun) is covered by a $6 \mathrm{~mm}$ thick cell polycarbonate transparent sheet. The area of the absorber's working surface is $1.8 \mathrm{~m}^{2}$, and its mass - about $27 \mathrm{~kg}$. The volume of the heat 
carrier (water) into the absorber is about 5 litres. At the determination of the size of the collector's box, the coefficient of linear expansion $\left(0.067 \mathrm{~mm} /\left(\mathrm{mm} \cdot{ }^{\circ} \mathrm{C}\right)\right)$ of the cell polycarbonate was taken into consideration. Accepting that the collector works at the temperature from $-35^{\circ} \mathrm{C}$ up to $+100^{\circ} \mathrm{C}$, it was stated that the length of $2 \mathrm{~m}$ (at $20^{\circ} \mathrm{C}$ ) long cell polycarbonate sheet will change by $18 \mathrm{~mm}$. The collector box (frame) from wooden boards was made. They are mechanically durable, with good heat insulation ability and, as practise has shown, in outside conditions can work from 10 to 20 years.

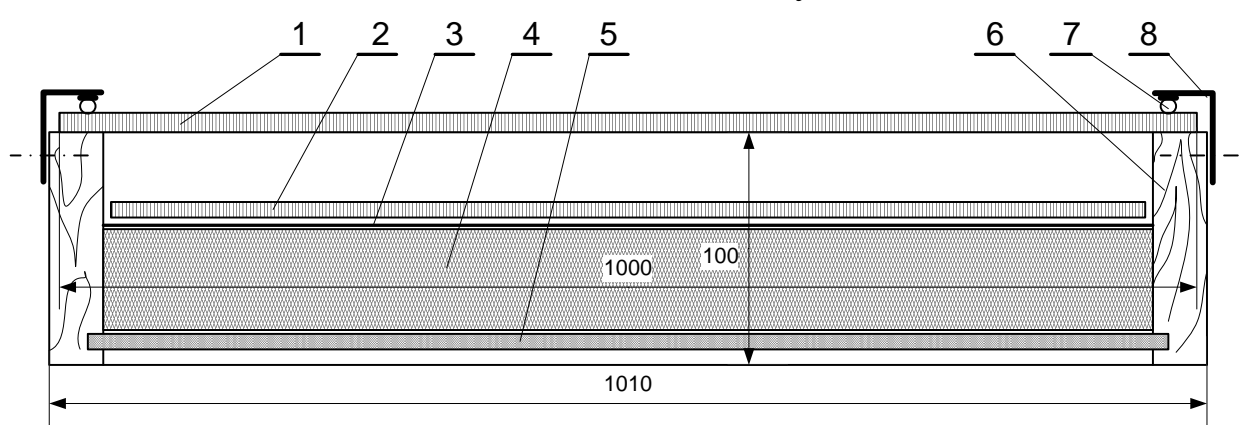

Fig.1. Cross-section of the cell polycarbonate sheet collector:

1 - transparent cover (CPC, $6 \mathrm{~mm}$ ), 2 - absorber (CPC, $4 \mathrm{~mm}$ ), 3 - mirror film, 4 - heat insulation (rock wool), 5 - rear lid (board), 6 - frame (wooden board), 7 - rubber gland, 8 - set square

The absorber of the cell polycarbonate collector consists of heat carrier inflow 4 and outflow 1 tubes and a sheet of cell polycarbonate 3 (Fig.2). The tubes 1 and 4 are made of polycarbonate and have milled chinks, which length and width corresponds to the length and width of the polycarbonate sheet 3 . The ends of the sheet are glued into the chinks, using junctions 2 and discs 5 .

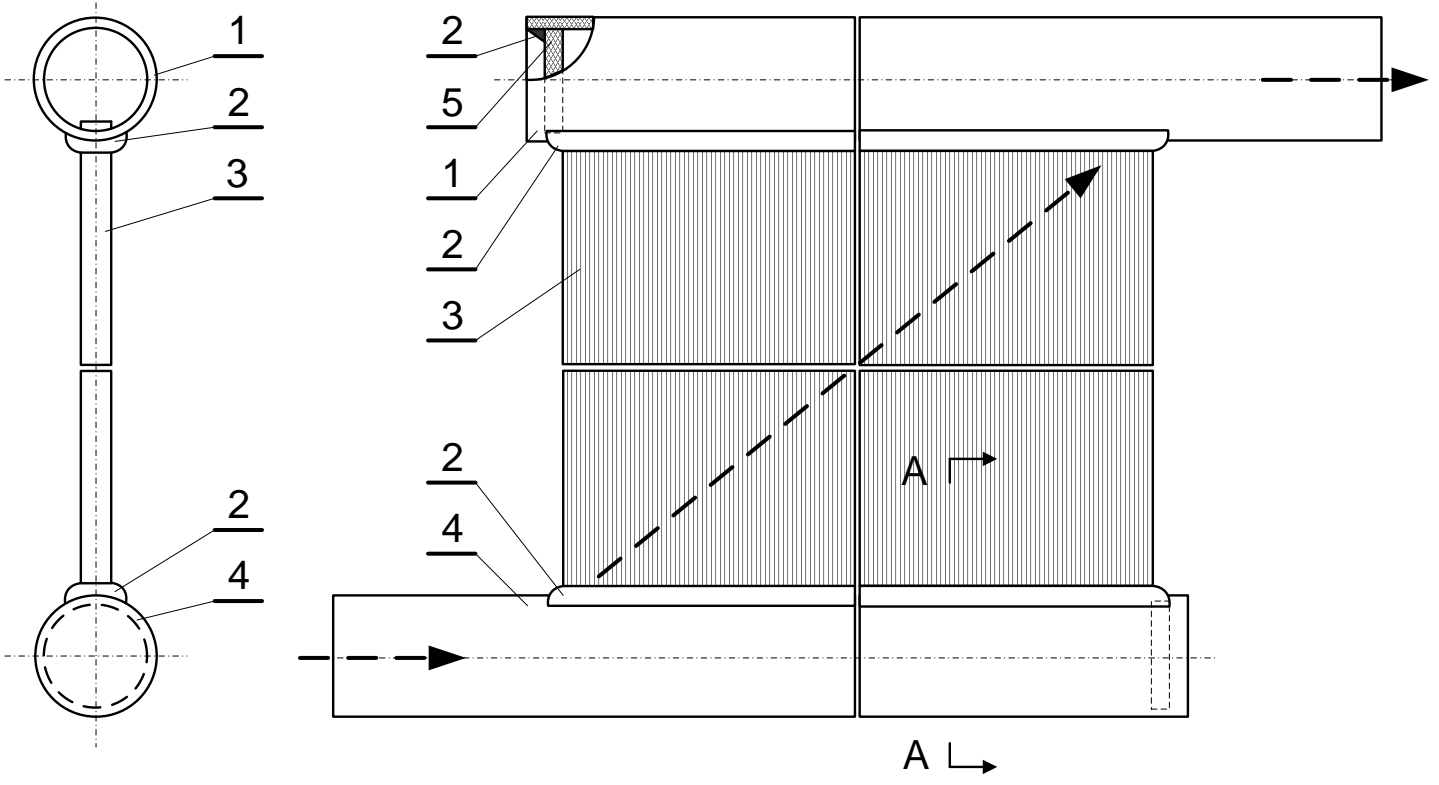

Fig.2. Absorber of the cell polycarbonate collector:

1 - outflow tube, 2 - junctions, 3 - cell polycarbonate sheet, 4 - inflow tube, 5 - disc

The solar radiation, striking the transparent cover, goes through it. The length of the solar electromagnetic waves on the earth surface is in the range of 0.4 to $2.4 \mu \mathrm{m}$. Therefore as a transparent cover ordinary or hardened glass panes are used, which coefficient of transparently is up to $90 \%$. It means, the absorber, placed under the glass, absorbs up to $90 \%$ of striking it solar radiation energy. Solar radiation transforms into the heat energy in the absorber. A hot absorber irradiates heat energy, the frequency of which is in the range of 
infrared radiation (maximum about $8 \mu \mathrm{m}$ ); such waves do not go back from the absorber through the glass cover. It means the heat losses in the collector occur only by convection and conduction through the transparent cover.

A solar collector can work only together with the corresponding equipment. In point of fact, the main component of the solar collector system is a hot water basin 12 (Fig.3), to which a loop of the solar collector and a loop of hot water are connected. The collector's loop includes a heat exchanger 11 , one way valve 9 , circulation pump 8 , expansion compensation vessel 5 with security valve 6 , solar collector 3 , heat carrier inflow valve 1 , heat carrier and air outflow valve 4 . All these components are connected with cupper tubes through which, when the circulation pump 8 is operating, liquid heat carrier is circulating and transporting the heat from the collector to the hot water basin 12. For an automatic control of the pump 8 operation a control device 7 with temperature sensors 2 and 10 is envisaged. When the temperature, measured by the sensor 2, becomes for some degrees higher as the temperature stated by the sensor 10, the pump 8 switches on, but when the temperature difference decreases, it switches off. The hot water loop consists from an expansion compensation vessel 14, valves 13 and 15 . Through the valve 13 the hot water is delivered to consumers, but through the valve 15 , the cold water flows into the tank 12.

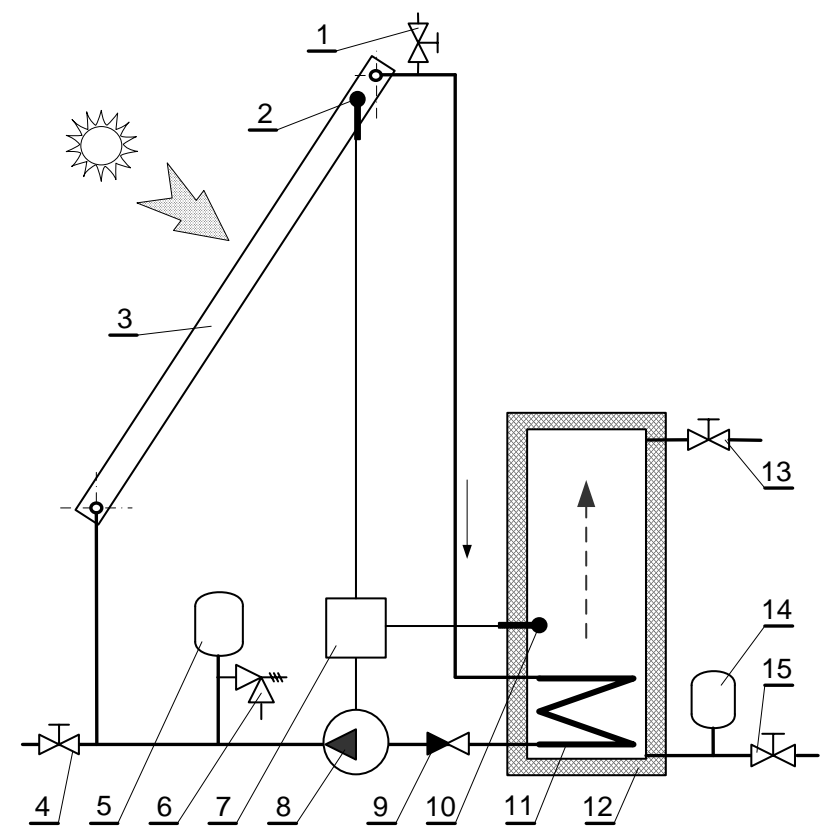

Fig.3. Functional scheme of the solar collector equipment:

1, 4, 15 - valves, 2, 10 - temperature sensors, 3 - solar collector, 5 - expansion compensation vessel, 6 - security valve, 7 - control device, 8 - circulation pump, 9 - one way valve, 11 - heat exchanger,

$$
12 \text { - hot water tank }
$$

The heat energy power of a flat plate solar collector can be calculated using Hottel-UillerBliss equation [3]:

$$
P_{c}=A\left[P_{s} \cdot \eta_{o}-K_{l}\left(T_{h}-T_{o}\right)\right],
$$

where $P_{c}$ - power of solar collector, W;

$A$ - collector's surface area, $\mathrm{m}^{2}$;

$P_{s}$ - intensity of solar radiation, $\mathrm{W} / \mathrm{m}^{2}$;

$\eta_{o}$ - collector's optical coefficient;

$K_{l}-$ collector's heat loss coefficient, $\mathrm{W} /\left(\mathrm{m}^{2} \cdot{ }^{\circ} \mathrm{C}\right)$;

$T_{h}$ - heat carrier temperature, ${ }^{\circ} \mathrm{C}$;

$T_{o}$ - surrounding air temperature, ${ }^{\circ} \mathrm{C}$. 
The collector's optical coefficient is calculated using formula (2):

$$
\eta_{o}=\tau \cdot \alpha,
$$

where $\tau$-coefficient of solar radiation penetrability (0.6-0.95);

$\alpha$-absorption coefficient of solar radiation (0.85-0.98).

The collector's optical coefficient does not depend on the sollar radiation intensity, as well as the temperature difference between the heat carrier and surrounding air. The coefficient of solar collector efficiency (3) is the ratio between the amounts of heat energy produced by the collector and received by the working surface of the collector. Divided both sides of the equation (1) by the intensity of solar radiation $\mathrm{P}_{\mathrm{s}}$, we will obtain:

$$
\eta_{c}=\eta_{o}-K_{l} \frac{T_{h}-T_{o}}{P_{s}} .
$$

The value of the coefficient of solar collector's efficiency (3) is dependent on:

- the meteorological parameters, like the intensity of the solar radiation and air temperature,

- constructive parameters of the collector such as the heat absorption ability of the absorber, the transparent cover penetrability of the solar radiation, the sickness of the heat insulation and its coefficient of the heat conductivity,

- such operational parameters of the collector as consumption of heat and temperature.

The numerical values of a flat plate solar collector optical and heat loss coefficients depend on the type of the collector and its construction (Table 1).

Table 1.

\section{Numerical values of optical and heat loss coefficients for different kind of solar collectors}

\begin{tabular}{|l|c|c|}
\hline \multicolumn{1}{|c|}{ Type of collector } & $\begin{array}{c}\text { Optical coefficient, } \\
\boldsymbol{\eta}_{\mathbf{0}}\end{array}$ & $\begin{array}{c}\text { Heat loss coefficient, } \mathbf{K}_{\mathbf{l}}, \\
\mathbf{W} /\left(\mathbf{m}^{\mathbf{2}}{ }^{\circ} \mathbf{C}\right)\end{array}$ \\
\hline Non selective and without a cover & 0.95 & 15 \\
\hline Non selective with one glass cover & 0.85 & 7 \\
\hline Non selective with two glass covers & 0.75 & 5 \\
\hline Selective with one glass cover & 0.80 & 3.5 \\
\hline Vacuum tube absorber & 0.75 & 2 \\
\hline
\end{tabular}

When caring out the experimental investigation of solar collectors, it is possible to determine produced by them heat energy and its coefficient of efficiency knowing or experimentally obtaining the inflow and outflow heat carrier temperature, circulation pump operation intensity and the heat carrier heat capacity. In this case the power of a solar collector is calculated by formula [3]:

$$
P_{c}=g \cdot C_{c} \cdot\left(T_{\text {out }}-T_{\text {in }}\right),
$$

where $g$-consumption of heat energy, $\mathrm{kg} / \mathrm{s}$;

$C_{c}$ - heat capacity of heat carrier, $\mathrm{J} /\left(\mathrm{kg} \cdot{ }^{\circ} \mathrm{C}\right)$, water $C_{c}=4.19 \cdot 10^{3} \mathrm{~J} /\left(\mathrm{kg} \cdot{ }^{\circ} \mathrm{C}\right)$;

$\left(T_{\text {out }}-T_{\text {in }}\right)$ - difference between heat carrier outflow and inflow temperature, ${ }^{\circ} \mathrm{C}$.

If the consumption of heat $\mathrm{g}$ is given in kilograms per hour $(\mathrm{kg} / \mathrm{h})$, the power of a solar collector in watts (W) can be calculated as:

$$
P_{c}=\frac{g \cdot 4.19 \cdot 1000 \cdot\left(T_{\text {out }}-T_{\text {in }}\right)}{3600}=1.161 \cdot g \cdot\left(T_{\text {out }}-T_{\text {in }}\right) .
$$

The coefficient of the efficiency for a certain solar collector with working area A by formula (6) can be figured [3]:

$$
\eta_{c}=\frac{P_{c}}{P_{s} \cdot A}
$$


As the CPC collector was made at the end of the last year summer, only first experimental results have been obtained. The examination will be continued, as the objective of the research is to ascertain the efficiency of the collector as a function from the temperature difference between the collector's absorber and surrounding air. The obtained results will be compared with the same parameters of similar metal-glass (MG) collectors.

For the experimental investigation of the collector, a special stand has been used (Fig.4 and Fig.5). In point of fact, the stand is a platform with wheels, on which a 30 litres barrel 6, one way valve 5, heat carrier circulation pump 4, heat meter (M-CAL compact 0.6) 3 and solar collector 1 are placed (Fig.4).

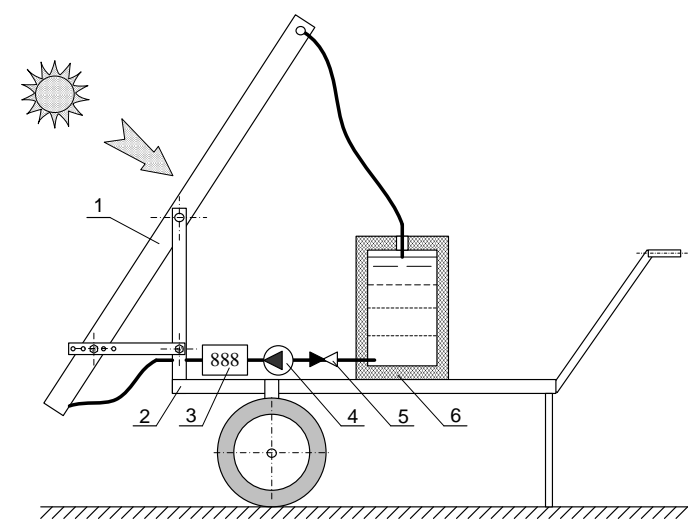

Fig.4. Principal scheme of mobile stand for solar collectors' experimental investigation

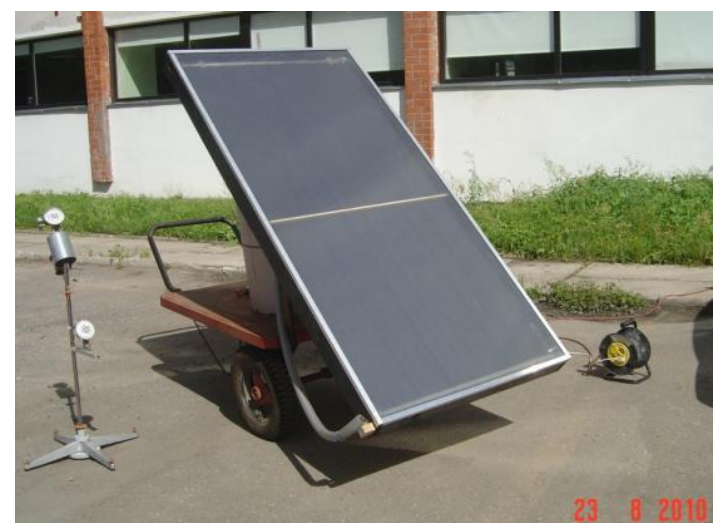

Fig.5. Mobile stand for solar collectors' experimental investigation (look from the outside)

Meteorological parameters during the investigation by the device MD-4 were measured (Fig.5, from left). As the used heat meter was not provided with an automatic data registration, the data for formulas (4) and (5) (pump productivity and temperatures $T_{\text {in }}, T_{\text {out }}$ ) during the examination after the accepted time interval were red. The intensity of the solar radiation $P_{s}$ and the surrounding air temperature $T_{o}$ automatically by the device MD-4 (logger HOBO H08) have been registered. In order to compare the cell polycarbonate collector's parameters with those of a metal-glass collector, like the coefficient of efficiency as a function from the difference of the heat carrier and surrounding air temperature, formulas (1) and (3) and data from Table 1 (for the cover of one pane of glass with $\eta_{0}=0.85$ and $K_{1}=7$ ) were used (Fig.6). During the experimental investigation the collector perpendicularly to the sun beams has been orientated.

\section{Results and discussion}

The obtained experimental results are presented in Fig.6 and Fig.7. In Fig.6 the curves of water heating process on August 16, 2010, but in Fig.7 the comparison of efficiency of the $\mathrm{CPC}$ and metal-glass collector are given. Materials used for the manufacturing of the CPC collector $\left(1.8 \mathrm{~m}^{2}\right)$ and its prices in Table 2 are shown. 


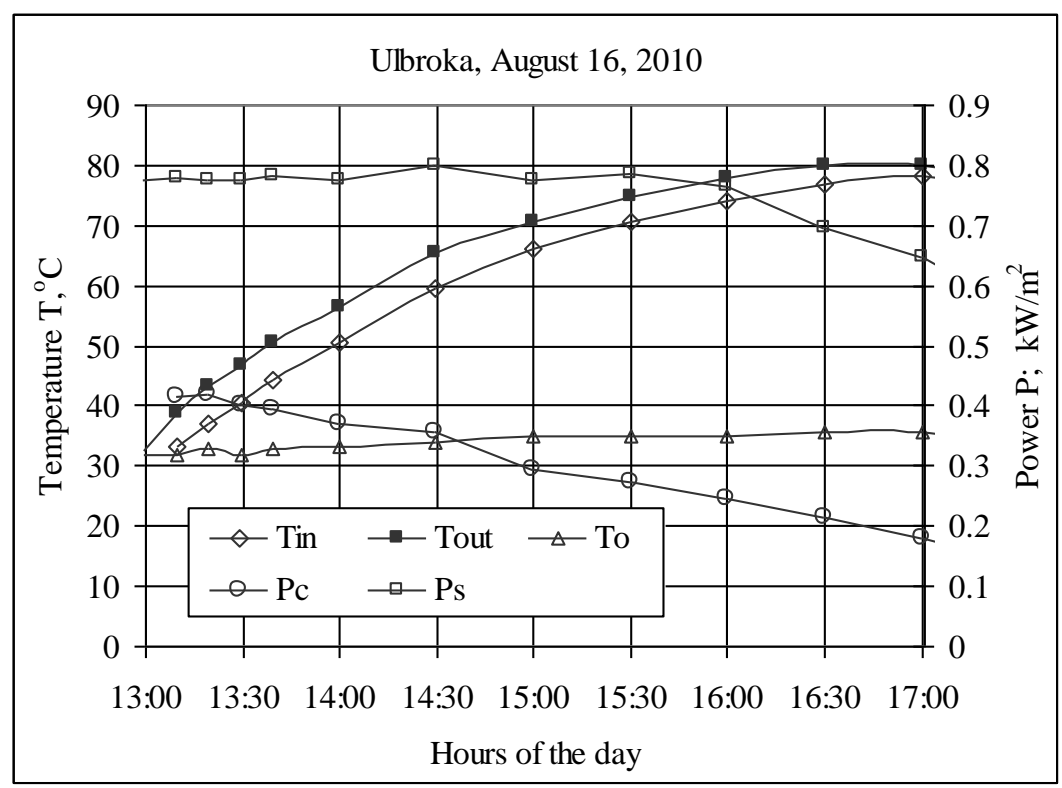

Fig.6. Parameters of the CPC collector depending on the heating time: $\mathbf{T}_{\text {in }}, \mathbf{T}_{\text {out }}-$ heat career inflow and outflow temperatures of the absorber, ${ }^{\circ} \mathrm{C} ; \mathrm{T}_{\mathbf{0}}$ - surrounding air temperature, ${ }^{\circ} \mathrm{C} ; \mathrm{P}_{\mathrm{c}}-$ specific power of the collector, $\mathrm{kW} / \mathrm{m}^{2} ; \mathrm{P}_{\mathrm{s}}-$ intensity of solar radiation, $\mathrm{kW} / \mathrm{m}^{2}$

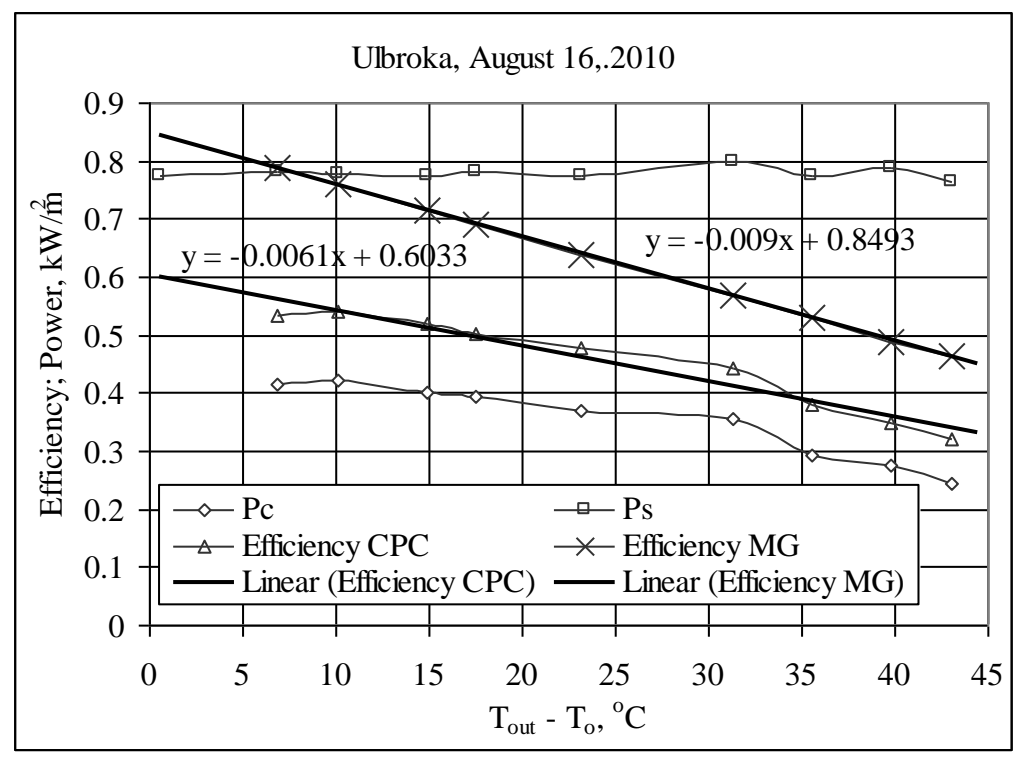

Fig.7. Efficiency of CPC collector in comparison with the calculated efficiency of the metal-glass collector at the solar radiation intensity $\mathbf{P}_{\mathrm{s}}$

As it is seen from Fig.6, at the solar radiation intensity about $780 \mathrm{~W} / \mathrm{m}^{2}$ the cell polycarbonate collector 36 litres of water (30 1 in the hot water tank and 61 into the collector's absorber) during 3 hours has heated by $43^{\circ} \mathrm{C}$. During the heating time collector's coefficient of efficiency from $60 \%$ has decreased to $33 \%$ (Fig.7). 
Materials used for production of the CPC collector and its prices

\begin{tabular}{|c|l|c|c|c|}
\hline $\mathbf{N}^{\circ}$ & \multicolumn{1}{|c|}{ Material } & $\begin{array}{c}\text { Parameters of the } \\
\text { material }\end{array}$ & Amount & Price, $\boldsymbol{\epsilon}$ \\
\hline 1 & CPC sheet & Thickness $4 \mathrm{~mm}$ & $2 \mathrm{~m}^{2}$ & 11.29 \\
\hline 2 & CPC sheet & Thickness $6 \mathrm{~mm}$ & $2 \mathrm{~m}^{2}$ & 18.36 \\
\hline 3 & CPC section & U-shape $10 \mathrm{~mm}$ & $2.05 \mathrm{~m}$ & 4.49 \\
\hline 4 & Wood-waste board OSB-3 & Thickness $3.8 \mathrm{~mm}$ & $2.05 \mathrm{~m}^{2}$ & 10.78 \\
\hline 5 & Wooden board & $30 \times 100 \mathrm{~mm}$ & $6 \mathrm{~m}$ & 4.17 \\
\hline 6 & Aluminium section & $20 \times 20 \mathrm{~mm}$ & $6 \mathrm{~m}$ & 10.44 \\
\hline 7 & Rockwool & Thickness $50 \mathrm{~mm}$ & $2 \mathrm{~m}^{2}$ & 3.71 \\
\hline 8 & Mirror film & Aluminium & $2 \mathrm{~m}^{2}$ & 2.53 \\
\hline 9 & Glue & Terostat & $78 \mathrm{ml}$ & 2.85 \\
\hline 10 & Thinner & Teroson & $100 \mathrm{ml}$ & 0.90 \\
\hline & & & Total & $\mathbf{6 9 . 5 2}$ \\
\hline
\end{tabular}

In comparison with the metal-glass solar collector efficiency it is by $30 \%$ lower. Similar results are obtained by other researchers [4] and on the one hand it can be considered as the shortage of the CPC collectors. On the other hand, from Table 2 it is seen that the production of CPC collector is cheaper, only about $70 €$, what is considerably lower than the price of metal-glass collector and its weight is only $13 \mathrm{~kg} / \mathrm{m}^{2}$.

\section{Conclusions}

1. During the experimental examination the maximum temperature of the heat carrier reached $80^{\circ} \mathrm{C}$ at the intensity of solar radiation about $0.8 \mathrm{~kW} / \mathrm{m}^{2}$ and ambient air temperature about $32^{\circ} \mathrm{C}$.

2. The efficiency of the cell polycarbonate collector was $33-60 \%$, depending on the intensity of the solar radiation and surrounding air temperature. It is by $30 \%$ lower than of nonselective metal-glass collector, but its price is only about $40 € / \mathrm{m}^{2}$, which is much cheaper than of metal-glass collector.

\section{Acknowledgment}

Research is completed by financial support of European Structural Fund: Attraction of human resources for investigation of renewable energy resources. Realized by the Project Department of Latvia University of Agriculture (contract no. 2009/0225/1DP/1.1.1.2.0/09/APIA/VIAA/129).

\section{References}

1. Дж. Твайделл, А.Уэйр. Возобновляемые источники энергии. М. Энергоиздат, 1990, 390 стр.

2. Д. Мак - Вейч. Применение солнечной энергии. Энергоиздат, 1981, 208 стр.

3. Н.В. Харченко. Индивидуальные солнечные установки. М. Энергоиздат, 1991, 208 стр.

4. А.В.Дорощенко, В.В.Костенюк. Перспективы развития солнечных коллекторов из полимерных материалов. Холодильная техника и технология, № 1 (117), Одесса, 2009.

Anotācija. Izgatavots un eksperimentāli pārbaudīts saules enerğijas kolektors, kura absorberis un caurspīdīgais pārsegums izgatavoti no šūnu polikarbonāta loksnēm. Kolektora lietderības koeficients ir 33-60\% robežās atkarībā no saules starojuma intensitātes un apkārtējā gaisa temperatūras. 